\section{Technical and Technological Education in Britain}

Is his presidential address to the Association of Teachers in Technical Institutions, delivered at Leeds on May 24, Mr. C. L. Bott, principal of Southport Technical College, referred to the lack of progress in secondary technical education in Britain, and to the need for careful thought as to what exactly the secondary technical schools are intended to do. Mr. Bott visualizes them as catering for three groups of students : a few who would proceed to a university or college of technology ; those of a less academic type who require the stimulus of a more practical type of training; and those who would ultimately be trained as technicians. He emphasized the necessity for effective and continuous education from the secondary technical schools whether to a university or to a technical college, but he made the surprising remark, in view of what has been said, for example, at recent conferences of the Federation of British Industries, that firms now find difficulty in training workers themselves and look more and more to the technical colleges. He also commended the provision of sandwich courses: both education and industry are convinced, he said, that such schemes could ensure a sound integration and correlation of works and college training, and he thought that the scope and number of such schemes could be extended with advantages both to students and the community as $a_{0}$ whole. In his reference to higher technological education, Mr. Bott was less happy, pursuing the chimera of a national award, which the Government has wisely rejected; he passed over the vital questions of adequate resources and conditions which will attract staff of high calibre, both of which are essential to enable the technical colleges to contribute significantly to the supply of technologist.s. Nor did he distinguish clearly between technician and technologist, or discuss the importance of an appropriate numerical balance between the two.

\section{National Research Council of Canada: New Members}

THREe new members have been appointed as follows to the National Research Council of Canaida for a three-year term ending on March 31, 1956 : Dr. R. F. Farquharson, Sir John and Lady Eaton professor of medicine and head of the Department of Medicine, University of Toronto; Dr. E. G. D. Murray, professor and chairman of the Department of Bacteriology and Immunology, Faculty of Medicine, McGill University ; Dr. David L. Thomson, dean of the Faculty of Graduate Studies and Research and chairman of the Department of Biochemistry, McGill University. In addition, the following three members, who have already served one term on the Council, have been reappointed for another three years : Dr. C. W. Argue, dean of science and professor of biology, University of New Brunswick; Dr. A. G. McCalla, dean of agriculture, University of Alberta ; Dr. G. M. Shrum, professor and head of the Department of Physics, University of British Columbia. The National Research Council consists of a president, two vice-presidents and seventeen members. The members serve in an honorary capacity for a threeyear term which may be renewed once; they are appointed by Order-in-Council and are chosen to represent the universities and industry, the selection being made in such a way as also to provide adequate geographical representation.

\section{Colonial Service: Recent Appointments}

ThE following appointments have recently been made in the Colonial Service: N. R. FugglesCouchman (agricultural officer, Tanganyika), regional assistant director of agriculture, Tanganyika; W. B. Mason (senior agricultural officer, Gold Coast), assistant director of agriculture, Gold Coast ; W. V. Rose (agricultural officer, Nyasaland), deputy director of agriculture, Barbados ; F. E. Hughes (conservator of forests, Gold Coast), deputy chief conservator of forests, Gold Coast ; H. S. H. Watson (senior assistant conservator of forests, Northerm Rhodesia), deputy conservator of forests, Northern Rhodesia; A. T. Crow (geologist, Gold Coast), senior geologist, Gold Coast ; F. H. Fitch (senior geologist, North Borneo), deputy director of geological surveys, North Borneo; E. G. Davy (assistant director of observatory, Mauritius), director of observatory, Mauritius; E. G. B. Jones (agricultural instructor, British Guiana), agricultural officer, Jamaica; Miss C. MeGlade (clerk, grade I, Statistical Department, East Africa), statistician, Statistical Department, East Africa; J. C. Williams (engineering surveyor, Water Development Department, Tanganyika), topographer, Department of Geological Survey, Uganda ; S. J. A. Williams, agricultural officer, British Honduras; J. Armour, veterinary officer, Nigeria; N. St. G. Hyslop, veterinary research officer, Kenya ; W. P. Unsworth, veterinary officer, Department of Agriculture, Trinidad; C. S. Eastman, assistant conservator of forests, Nigeria ; M. Garstang, assistant meteorologist, British Caribbean Meteorological Service, Trinidad; V. E. Sills, biochemist, Agricultural Department, Fiji.

\section{Physical Society: Officers}

AT the annual general meeting of the Physical Society held on May 15 the following officers were elected : President, Prof. R. Whiddington; Honorary Secretaries, Mr. C. G. Wynne and Dr. H. H. Hopkins; Honorary Treasurer, Mr. A. J. Philpot; Honorary Foreign Secretary, Prof. E. N. da C. Andrade; Honorary Librarian, Dr. R. W. B. Pearse; New Members of Council, Prof. P. M. S. Blackett, Prof. N. Feather and D. W. Fry.

\section{Fourteenth International Congress of Zoology}

THE Fourteenth International Congress of Zoology will take place in Copenhagen during August 5-12, and more than five hundred zoologists from fortyfour countries outside Denmark have already indicated that they will be present. 'The president of the Congress will be Dr. R. Spärck, professor of zoology, University, Copenhagen, and the secretary-general, Dr. Anton Fr. Bruun, Zoological Museum of the University, Copenhagen. Those who wish to become members of the Congress are invited to apply to the Secretariat, Krystalgade 27, Copenhagen K, Denmark. The membership fee is 100 Danish kroner (about f5). Associate membership costs 50 Danish kroner, but does not entitle the member to receive the proceedings of the Congress. Accommodation may be arranged through any travel agency, and the secretariat is also prepared to arrange hotel accommodation for members but applications should be made as early as possible. A preliminary list of twenty sections of zoology has been suggested, so that it will be possible for members to meet their colleagues in fairly restricted fields, but more sections may be established depending upon the 